\title{
Dopuszczalność wprowadzania do obrotu produktów przetworzonych przez grupy producentów rolnych
}

\section{Wprowadzenie}

Grupy producentów rolnych stanowią ważne narzędzie realizacji Wspólnej Polityki Rolnej Unii Europejskiej oraz polityki rolnej państw członkowskich. W ramach tych polityk tworzone są zachęty i ułatwienia dla rolników do organizowania się w trwałe i rentowne podmioty w celu dostosowania produktów rolnych i procesu produkcyjnego do wymogów rynkowych, wspólnego wprowadzania towarów do obrotu, w tym przygotowania do sprzedaży, centralizacji sprzedaży i dostawy do odbiorców hurtowych, ustanowienia wspólnych zasad dotyczących informacji o produkcji ze szczególnym uwzględnieniem zbiorów i dostępności produktów rolnych, rozwijania umiejętności biznesowych, marketingowych oraz organizowania i ułatwiania procesów wprowadzania innowacji, a także ochrony środowiska naturalnego ${ }^{1}$.

Zadania, których realizacja przez grupy producentów rolnych jest postulowana w literaturze ${ }^{2}$, obejmują dodatkowo wspólne zaopatrywanie się

${ }^{1}$ Art. 2 ust. 1 pkt 2 ustawy o grupach producentów rolnych i ich związkach oraz o zmianie innych ustaw z 15 września 2000 r. (Dz. U. Nr 88, poz. 983 ze zm.; dalej: ustawa o grupach). Por. art. 27 ust. 1 rozporządzenia Parlamentu Europejskiego i Rady (UE) nr 1305/2013 z 17 grudnia 2013 r. w sprawie wsparcia rozwoju obszarów wiejskich przez Europejski Fundusz Rolny na rzecz Rozwoju Obszarów Wiejskich (EFRROW) i uchylającym rozporządzenie Rady (WE) nr 1698/2005 (Dz. Urz. UE L 347 z 20.12.2013 r.; dalej: rozporządzenie nr 1305/2013).

${ }^{2}$ A. Suchoń, Z aktualnej problematyki zakładania i funkcjonowania grup producentów rolnych, „Przegląd Prawa Rolnego” 2016, nr 2, s. 98; G. Czapiewska, Grupy producentów rolnych 
w środki do produkcji rolnej, inwestycje, a nawet prowadzenie działalności kredytowej i ubezpieczeniowej. Główną przyczyną powstania i rozwoju odpowiednich regulacji prawnych była, i nadal jest, potrzeba poprawy struktur rolnych w Unii Europejskiej ${ }^{3}$ oraz realizacji postulatów zawartych $\mathrm{w}$ art. 39 ust. 1 traktatu rzymskiego ${ }^{4}$, w tym podniesienie indywidualnego dochodu osób pracujących w rolnictwie. Działanie zespołowe w założeniu powinno także wzmacniać pozycję producentów rolnych w łańcuchu żywnościowym oraz sprzyjać zwiększaniu ich udziału w wartości dodanej ${ }^{5}$. Współpraca z grupą producentów ma również przynosić korzyści odbiorcy surowca ze względu na gwarancję regularnych dostaw, dostosowania ich wielkości do potrzeb, odpowiedniej i wyrównanej jakości surowca ${ }^{6}$.

Jedną z aktywności, które podejmują grupy, jest przetwarzanie produktów rolnych pochodzących zarówno z gospodarstw swoich członków, jak i spoza tego grona. Ta aktywność grup producentów rolnych, w odróżnieniu od grup producentów owoców i warzyw ${ }^{7}$, podejmowana jest przez niewielki odsetek organizacji w Polsce. Dominującym modelem jest wprowadzanie do obrotu przez grupy produktów rolnych nieprzetworzonych, pochodzących wyłącznie z gospodarstw swoich członków.

W działalności grup producentów rolnych może pojawić się problem przetwarzania w następujących okolicznościach:

a) członek grupy produkuje i przetwarza produkt rolny pochodzący $\mathrm{z}$ jego gospodarstwa i w takiej formie dostarcza do grupy, która następnie wprowadza go do obrotu,

b) członek grupy produkuje i dostarcza do grupy surowy produkt rolny, a grupa (własnymi zasobami lub usługowo) przetwarza go, a następnie wprowadza do obrotu,

w rozwoju obszarów wiejskich Pomorza, ,Acta Universitatis Lodziensis. Folia Geographica Socio-Oeconomica" 2013, nr 13, s. 168-169; M. Lemanowicz, Grupy producenckie i marketingowe i ich wptyw na pozycję konkurencyjna rolników na rynku, „Acta Scientiarum Polonorum. Oeconomia” 2004, nr 3, s. 105; B. Oleszko-Kurzyna, Postawy rolników wobec grup producentów rolnych, „Annales Universitatis Mariae Curie-Skłodowska, Sectio H Oeconomia” 2007, nr 41, s. 165.

${ }^{3}$ A. Lichorowicz, Problematyka struktur agrarnych w ustawodawstwie Wspólnoty Europejskiej, Kraków 1996, s. 205-206.

${ }^{4}$ Traktat ustanawiający Europejską Wspólnotę Gospodarczą z 25 marca 1957 r. (niepublikowany w Dzienniku Urzędowym), https://eur-lex.europa.eu/eli/treaty/teec/sign [dostęp: 9.11.2020].

${ }^{5}$ A. Suchoń, Grupy i organizacje producentów rolnych wobec wyzwań Wspólnej Polityki Rolnej 2014-2020, ,Studia Iuridica Agraria” 2015, nr 13, s. 135.

${ }^{6}$ Program Rozwoju Obszarów Wiejskich na lata 2014-2020, wersja z 9 kwietnia 2019 r., https:// www.gov.pl/attachment/5c886e0c-2bae-4089-8484-8b2b45be97b9, s. 343 [dostęp: 23.09.2019].

7 W myśl ustawy z 19 grudnia 2003 r. o organizacji rynków owoców i warzyw oraz rynku chmielu (Dz. U. Nr 223, poz. 2221 ze zm.). 
c) członek grupy produkuje i przetwarza produkt rolny, który dostarcza do grupy, a grupa poddaje go dalszemu przetworzeniu, po czym wprowadza do obrotu.

O ile pierwszy przypadek nie wzbudza wątpliwości, o tyle drugi nie został uwzględniony expressis verbis w przepisach prawa unijnego i krajowego ${ }^{8}$ dotyczącego zakładania i funkcjonowania grup producentów rolnych, natomiast stał się przedmiotem wątpliwości, których przejawem były m.in. sprzeczne stanowiska organów administracji publicznej. Przypadek trzeci, choć stanowi w zasadzie wariant poprzedniego, wskazuje jednocześnie na złożoność i wagę problemu.

Celem rozważań jest zatem próba odpowiedzi na pytanie, czy w świetle obowiązujących przepisów prawa krajowego i wspólnotowego uznane grupy producentów mogą przetwarzać produkty rolne dostarczone przez członków lub podmioty spoza tego grona, by potem wprowadzać je do obrotu. Za podjęciem tej tematyki przemawiają przede wszystkim względy praktyczne. Problem przetwarzania produktów rolnych przez grupy uznane na podstawie ustawy o grupach ma bezpośredni wpływ na ocenę spełniania przez grupę warunków tego uznania, a także utrzymania lub utraty tego statusu i co za tym idzie przywilejów z nim związanych w postaci pomocy finansowej ze środków UE, zwolnień podatkowych ${ }^{9}$ czy dopłat do kredytów preferencyjnych ${ }^{10}$.

\section{Początki wspólnotowej regulacji dotyczącej grup producentów}

W legislacji wspólnotowej pierwszym aktem normującym materię grup producenckich ${ }^{11}$ było rozporządzenie Rady (EWG) nr 1360/78 z 19 czerwca 1978 r. w sprawie grup producentów i ich zrzeszeń ${ }^{12}$. Uregulowano w nim

${ }^{8}$ A. Suchoń, Z aktualnej problematyki..., s. 102.

${ }^{9}$ Art. 17 ust. 1 pkt 49 ustawy z 15 lutego 1992 r. o podatku dochodowym od osób prawnych (Dz. U. Nr 21, poz. 86 ze zm.); art. 7 ust. 1 pkt 13 ustawy z 12 stycznia 1991 r. o podatkach i opłatach lokalnych (Dz. U. z 1992 r., Nr 9, poz. 31 ze zm.).

${ }^{10}$ Rozporządzenie Rady Ministrów z 27 stycznia 2015 r. w sprawie szczegółowego zakresu i sposobów realizacji niektórych zadań Agencji Restrukturyzacji i Modernizacji Rolnictwa (Dz. U. poz. 187).

${ }^{11}$ Pojęcie ustawowe to „grupa producentów rolnych”, natomiast w literaturze przedmiotu z różnych dziedzin nauki (prawo, ekonomia, zarządzanie) spotyka się synonimiczne określenie „grupa producencka”. Zob. np. K. Łęczycki (red.), Ogólne problemy rozwoju grup producenckich w rolnictwie, Siedlce 2007; A. Parzonko (red.), Sposoby wspótpracy doradców z rolnikami zorganizowanymi w grupy producentów rolnych, Warszawa 2008; A. Chlebicka, J. Fałkowski, T. Wołek, Powstawanie grup producenckich a zmienność cen, „Zagadnienia Ekonomiki Rolnej” 2009, nr 2.

12 Rozporządzenie Rady (EWG) nr 1360/78 z 19 czerwca 1978 r. w sprawie grup producentów i ich zrzeszeń (Dz. Urz. UE L 166 z 26.06.1978 r.). 
kwestię warunków uznawania, reżimu wewnętrznego organizacji, zasad cofania uznania oraz kwestię pomocy finansowej dla nich. Akt ten razem z rozporządzeniem Rady (EWG) nr 355/77 z 15 lutego 1977 r. w sprawie wspólnych środków polepszania warunków przetwarzania i marketingu produktów rolnych ${ }^{13}$ należał do pierwszych sześciu aktów prawnych (trzy dyrektywy i trzy rozporządzenia) realizujących założenia polityki strukturalnej (struktur rolnych) Europejskiej Wspólnoty Gospodarczej ${ }^{14}$. Podstawą tej polityki były założenia traktatu rzymskiego, w myśl których w ramach Wspólnej Polityki Rolnej, poza systemem wspierania cen i dochodów rolniczych, państwa członkowskie miałyby aktywnie wpływać na poprawę struktur rolnych ${ }^{15}$.

W literaturze wskazuje się na memorandum w sprawie reformy rolnictwa w EWG, przedłożone Komisji w 1968 r., zwane planem Mansholta, jako dokument o fundamentalnym znaczeniu dla kształtowania polityki strukturalnej na wiele lat ${ }^{16}$. Postulaty $\mathrm{w}$ nim zawarte zaczęły nabierać legislacyjnego kształtu od 1972 r., czyli dyrektywy modernizacyjnej ${ }^{17}$. Na pierwszą regulację dotyczącą przetwórstwa i marketingu produktów rolnych przyszło czekać do $1977 \mathrm{r}^{18}{ }^{18}$, a na dotyczącą grup producentów rolnych i ich związków - do 1978 r. ${ }^{19}$

W rozporządzeniu nr 355/77 krąg potencjalnych beneficjentów pomocy finansowej na projekty z zakresu przetwórstwa wskazany w art. 19 ust. 1 został zakreślony szeroko: „osoby fizyczne lub prawne lub ich grupy, które są ostatecznie odpowiedzialne za koszty realizacji projektu”. W połączeniu z warunkiem umieszczonym w art. 11: ,projekty muszą przyczyniać się do poprawy sytuacji podstawowej produkcji rolnej danego sektora; w szczególności muszą zagwarantować producentom podstawowego produktu rolnego adekwatny i trwały udział w wynikających z tego korzyściach ekonomicz-

${ }^{13}$ Rozporządzenie Rady (EWG) nr 355/77 z 15 lutego 1977 r. w sprawie wspólnych środków polepszania warunków przetwarzania i marketingu produktów rolnych (Dz. Urz. UE L 51 z 23.02.1977 r.; dalej: rozporządzenie nr 355/77).

${ }^{14}$ A. Lichorowicz, Problematyka struktur agrarnych..., s. 37-38; A. Jurcewicz, B. Kozłowska, E. Tomkiewicz, Polityka Rolna Wspólnoty Europejskiej w świetle ustawodawstwa i orzecznictwa, Warszawa 1995, s. 83-92.

15 A. Jurcewicz, B. Kozłowska, E. Tomkiewicz, Wspólna Polityka Rolna. Zagadnienia prawne, Warszawa 2007, s. 139.

${ }^{16}$ A. Lichorowicz, Problematyka struktur agrarnych..., s. 25; A. Jurcewicz, B. Kozłowska, E. Tomkiewicz, Polityka Rolna ..., s. 83.

${ }_{17}$ Dyrektywa Rady nr 159/72 z 17 kwietnia 1972 r. w sprawie modernizacji gospodarstw rolnych (Dz. Urz. UE L 96 z 23.04.1972 r.).

${ }_{18}$ Dz. Urz. UE L 51 z 23.02.1977 r.

19 Dz. Urz. UE L 166 z 26.06.1978 r. Choć pierwszy projekt tego rozporządzenia Komisja Europejska przedłożyła Radzie już w 1968 r. 
nych" sprawiło to, że zakwalifikowanie do grona potencjalnych beneficjentów wsparcia na projekty dotyczące przetwórstwa lub marketingu organizacji producentów rolnych nie wzbudzało wątpliwości. Warto zauważyć, że prawodawca wspólnotowy dostrzegł potrzebę prowadzenia działalności przetwórczej i marketingowej przez związki rolników, a nawet związki takich związków, czemu dał wyraz już w rozporządzeniu nr 26 z 4 kwietnia 1962 r. dotyczącym stosowania niektórych reguł konkurencji w odniesieniu do produkcji rolnej i handlu produktami rolnymi ${ }^{20}$. Akt ten w preambule zapewniał o szczególnej wadze, jaką przykłada do organizacji rolników w materii, którą regulował, a w art. 2 ustanawiał dla związków rolników, m.in. tych korzystających ze wspólnych urządzeń do przechowywania, obróbki lub przetwarzania produktów rolnych, szczególny rodzaj wyłączenia spod przepisów art. 85 traktatu zakazujących ograniczanie handlu wewnątrzwspólnotowego poprzez niedozwolone umowy i porozumienia.

$\mathrm{W}$ trakcie prac nad rozporządzeniem dotyczącym grup producentów rolnych Komitet Społeczno-Ekonomiczny w opinii z 24 listopada 1977 r. ${ }^{21}$ wyraził przekonanie, iż powstające w przyszłości grupy będą podejmować działalność przetwórczą. Postulował przy tym, by wprowadzić do projektowanego aktu warunek, zgodnie z którym produkty przetwarzane przez grupę powinny pochodzić z gospodarstw jej członków ${ }^{22}$. Giuseppe Vitale, autor kluczowego $\mathrm{w}$ procesie legislacyjnym dotyczącym rozporządzenia w sprawie grup raportu ${ }^{23}$, wyjaśniał, iż wejście w życie aktu dotyczącego przetwórstwa i marketingu produktów rolnych, z którego korzystać miały także grupy producentów rolnych, sprawiło, iż Komisja zarzuciła w nowym projekcie aktu pomysł pomocy finansowej na cele inwestycyjne, pozostawiając jedynie środki na działalność operacyjną.

Należy podkreślić, że celem rozporządzenia w sprawie grup producentów i ich zrzeszeń z 19 czerwca 1978 r. ${ }^{24}$ nie było wprowadzanie do

${ }^{20}$ Rozporządzenie $\mathrm{nr} 26$ z 4 kwietnia 1962 r.) dotyczącym stosowania niektórych reguł konkurencji w odniesieniu do produkcji rolnej i handlu produktami rolnymi (Dz. Urz. UE L 30 z 20.04.1962 r.; zastąpione rozporządzeniem Rady (WE) nr 1184/2006 z 24 lipca 2006 r. dotyczące stosowania niektórych reguł konkurencji w odniesieniu do produkcji rolnej i handlu produktami rolnymi (Dz. Urz. UE L 214 z 4.08 .2006 r.).

${ }^{21}$ Dz. Urz. UE C 59 z 8.03.1978 r., s. 25-30.

22 Ibidem, pkt 3.4, s. 27.

${ }^{23}$ G. Vitale, Raport sporządzony w imieniu Komisji Rolnictwa w sprawie zmienionego wniosku Komisji Wspólnot Europejskich do Rady (dok. 156/77) w sprawie rozporządzenia dotyczącego grup producentów i ich stowarzyszeń. Dokumenty robocze Parlamentu Europejskiego. Dokument nr 375/77 z 13 grudnia 1977 r. Dostępny na zamówienie w Archiwach Parlamentu Europejskiego.

${ }^{24}$ Rozporządzenie z 19 czerwca 1978 r. w sprawie grup producentów i ich zrzeszeń (Dz. Urz. UE L 166 z 23.06.1978 r.). 
systemu prawnego Wspólnoty nowej formy prawnej dla organizacji producentów rolnych, lecz systemowe wsparcie ich powstawania i doskonalenia działalności już istniejących ${ }^{25}$. Rada postanowiła (art. 5 ust. 2) upoważnić kraje członkowskie do uznawania podmiotów, do których należą osoby inne niż producenci rolni, pod warunkiem że statut zapewni kontrolę i podejmowanie decyzji w podmiocie rolnikom. W ten sposób stworzono możliwość, by członkami grup producentów mogli zostać także przetwórcy. Uwzględniono postulat z raportu Vitalego, by przepisami objąć również istniejące spółdzielnie, nie wykluczając przetwarzających produkty rolne, i by mogły one zyskać uznanie jako grupa producentów lub zostać członkiem takiej organizacji obok osób prowadzących gospodarstwa rolne ${ }^{26}$. Rozporządzenie nr 1360/78 definiowało także (art. 5 ust. 1) na potrzeby tej regulacji pojęcie ,producent”, którym mogła być każda osoba (także prawna) prowadząca gospodarstwo na terenie Wspólnoty, w tym przetwarzająca produkty rolne, o ile jednocześnie była producentem produktów pierwotnych.

\section{Wyrok w sprawie nr 107/80}

Omawiane akty prawne, ale także nieporuszane tutaj regulacje ${ }^{27}$, stanowiły podwaliny dla późniejszych unormowań wspólnotowej polityki struktur rolnych, kontynuowanej do dzisiaj ${ }^{28}$. Dyrektywy i rozporządzenia realizujące ową politykę charakteryzowały odrębne cele i zadania szczegółowe, dla których były przyjmowane, a łączyło je wspólne umocowanie w przepisach traktatu, ze szczególnym uwzględnieniem art. 42 i 43. Częściowo wspólny był także krąg adresatów norm prawnych z nich wynikających.

Na tym tle dosyć szybko pojawiła się wątpliwość, której rozstrzygnięcie stało się kluczowe dla wykładni przepisów polityki struktur rolnych na kolejne dekady. W sprawie nr 107/80 Adorno przeciwko Komisjii ${ }^{29}$ Trybunał

${ }^{25}$ A. Lichorowicz, Problematyka struktur agrarnych..., s. 206.

${ }^{26}$ G. Vitale, Raport..., s. 16.

27 Na przykład dyrektywa Komisji nr 268/75 z 28 kwietnia 1975 r. w sprawie rolnictwa na terenach górskich i górzystych oraz na obszarach o niekorzystnych warunkach gospodarowania (Dz. Urz. UE L 128 z 19.05.1975 r.).

28 Rozporządzenie Parlamentu Europejskiego i Rady (UE) nr 1305/2013 z 17 grudnia 2013 r. w sprawie wsparcia rozwoju obszarów wiejskich przez Europejski Fundusz Rolny na rzecz Rozwoju Obszarów Wiejskich (EFRROW) i uchylające rozporządzenie Rady (WE) nr 1698/2005 (Dz. Urz. UE L 347 z 20.12.2013 r.).

${ }^{29}$ Wyrok Trybunału z 3 czerwca 1981 r., sygn. akt 107/80, Adorno v. Komisja, ECLI: EU:C:1981:127. 
uznał, że projekt inwestycyjny rolnika (właściciela dwóch gospodarstw rolnych, w których prowadzona była uprawa winorośli i wytwarzane było wino) w zakresie poprawy przetwarzania i marketingu produktów rolnych pochodzących z tego gospodarstwa, w którym inwestycja ma być wykonana, w żaden sposób nie jest wyłączony z zakresu rozporządzenia nr 355/77, jeżeli może wnieść wkład w racjonalizację struktur przetwórstwa i marketingu. Sąd wskazał zatem dwa podstawowe kryteria, przez pryzmat których należy oceniać ewentualny zbieg norm prawnych wynikających z prawodawstwa dotyczącego struktur rolnych. Pierwsze, przedmiotowe, wyznaczone jest przez cel projektu, który musi wpisywać się w zadania rozporządzenia. Drugie, podmiotowe, zakłada, że ewentualne wykluczenie z grona beneficjentów ostatecznych (art. 19 rozporządzenia 355/77) powinno wynikać wprost $\mathrm{z}$ aktu prawnego. Można zatem uznać, że per analogiam stanowisko Trybunału będzie odnosić się także do grup producentów, które z pomocy w obszarze przetwórstwa i marketingu nie zostały wyłączone, a zatem spełniały kryterium podmiotowe, o którym mowa w wyroku.

Rozporządzenia w sprawie grup producentów rolnych i ich związków ${ }^{30}$ oraz w sprawie wspólnych środków polepszania warunków przetwarzania i marketingu produktów rolnych ${ }^{31}$ zostały uchylone i zastąpione rozporządzeniem nr 1257/199932. Motyw 44 preambuły stanowił, że w obliczu pomocy grupom i zrzeszeniom producentów przewidzianej w kilku aktach dotyczących wspólnych organizacji poszczególnych rynków ${ }^{33}$ nie ma już potrzeby udzielania szczególnego wsparcia grupom producentów w ramach rozwoju struktur rolnych. Utrzymana została natomiast pomoc na inwestycje $\mathrm{w}$ przetwarzanie i marketing produktów rolnych, której adresat, w tym grupy producentów, ponownie został zdefiniowany dość szeroko, jako osoba ostatecznie odpowiedzialna za finansowanie inwestycji

${ }^{30}$ Rozporządzenie Rady (EWG) nr 952/97 z 20 maja 1997 r. w sprawie grup producentów i ich związków (Dz. Urz. UE L 142 z 2.06.1990 r.). Akt ten zastąpił rozporządzenie nr 1360/78.

${ }^{31}$ Rozporządzenie Rady (EWG) nr 866/90 z 29 marca 1990 r. w sprawie wspólnych środków polepszania warunków przetwarzania i marketingu produktów rolnych (Dz. Urz. UE L 91 z 6.04 .1990 r.).

32 Oba akty zostały uchylone i zastąpione przez rozporządzenie Rady (WE) nr 1257/1999 z 17 maja 1999 r. w sprawie wsparcia rozwoju obszarów wiejskich z Europejskiego Funduszu Orientacji i Gwarancji Rolnej (EFOGR) oraz zmieniające i uchylające niektóre rozporządzenia (Dz. Urz. UE L 160 z 26.06.1999 r.).

${ }^{33}$ Na przykład pomoc dla organizacji producentów owoców i warzyw przewidziana w rozporządzeniu Komisji (WE) nr 411/97 z 3 marca 1997 r. w sprawie szczegółowych zasad stosowania rozporządzenia Rady nr 2200/96 w zakresie programów operacyjnych, funduszy operacyjnych i wsparcia finansowego ze środków UE (Dz. Urz. UE L 62 z 4.03.1997 r.); pomoc dla grup producentów tytoniu przewidziana w rozporządzeniu Rady (EWG) nr 2075/92 z 30 czerwca 1992 r. w sprawie wspólnej organizacji rynku surowca tytoniowego (Dz. Urz. UE L 215 z 30.07.1992 r.). 
w przedsiębiorstwie, której rentowność można wykazać oraz która spełnia minimalne normy dotyczące środowiska, higieny i warunków utrzymania zwierząt (art. 26 ust. 1).

\section{Ustawa o grupach producentów rolnych i ich związkach z 2000 r.}

W tym czasie w Sejmie RP trwały prace nad pierwszą polską ustawą o grupach producentów rolnych i ich związkach, która ostatecznie została uchwalona 15 września 2000 r. ${ }^{34}$ Przepisy wzorowane na rozwiązaniach wspólnotowych ${ }^{35}$ bardzo ostrożnie - z racji słabej pozycji dopiero co powstających zrzeszeń, jak również całego sektora ${ }^{36}$ - zakreślały cele, dla których mogą być powoływane grupy. Większe oczekiwania ustawodawca ujawniał wobec związków grup, m.in. w zakresie „wstępnego przetwarzania” (art. 15 pkt 1 lit. c ustawy o grupach).

Polska ustawa, na wzór rozwiązań wspólnotowych, uwzględniła koncepcję limitowanej listy produktów, których producenci mogą tworzyć grupy (art. $6 \mathrm{w}$ zw. $\mathrm{z}$ art. 3 ust. 1 pkt 1 ustawy o grupach). Wydane na podstawie ustawowego upoważnienia rozporządzenie Ministra Rolnictwa i Rozwoju Wsi z 15 marca $2001 \mathrm{r}^{37}$ zawierało także produkty przetworzone, tj. mięso (wieprzowe, wołowe i inne). Nie ulegało zatem wątpliwości, iż grupę mogą tworzyć osoby fizyczne prowadzące gospodarstwo rolne i dostarczające do niej produkty w postaci przetworzonej. Przepisy ustawy o grupach z $2000 \mathrm{r}$. nie dawały natomiast expressis verbis odpowiedzi na pytanie, czy grupa może przetwarzać dostarczone przez swoich członków produkty rolne. Odpowiedzią może być swego rodzaju zachęta do podejmowania takiej aktywności przez grupy zawarta w art. 23 ustawy o grupach, wprowadzająca uprawnienie dla grup producentów do ubiegania się o preferencyjne kredyty inwestycyjne na takich zasadach jak dla kredytów inwestycyjnych w przetwórstwie rolno-spożywczym.

${ }^{34}$ Ustawa z 15 września 2000 r o grupach producentów rolnych i ich związkach (Dz. U. Nr 88, poz. 983 ze zm.).

${ }_{35}$ Uzasadnienie do projektu ustawy o grupach producentów rolnych i ich związkach, druk sejmowy nr 1002, http://orka.sejm.gov.pl/proc3.nsf/opisy/1002.htm [dostęp: 20.04.2020] (dalej: uzasadnienie do ustawy z 2000 r.); opinia Komitetu Integracji Europejskiej z 11 stycznia 1999 r., http://orka.sejm.gov.pl/Rejestrd.nsf/wgdruku/1866-A/\$file/1866-A.pdf [dostęp: 6.05.2020].

${ }^{36}$ Ibidem, s. 5-6.

${ }^{37}$ Rozporządzenie Ministra Rolnictwa i Rozwoju Wsi z 15 marca 2001 r. w sprawie wykazu produktów i grup produktów, dla których mogą być utworzone grupy producentów rolnych, minimalnej rocznej wielkości produkcji towarowej oraz minimalnej liczby członków grupy producentów rolnych (Dz. U. Nr 26, poz. 292 ze zm.). 
Niemal równocześnie trwały prace nad wdrożeniem w Polsce instrumentów pomocy finansowej, ustanowionych przez Radę WE rozporządzeniem nr 1268/1999 ${ }^{38}$ na rzecz krajów ubiegających się o członkostwo w Unii Europejskiej. Akt ów przewidywał (art. 2) m.in. możliwość udzielania dotacji na tworzenie grup producentów oraz poprawę przetwórstwa i obrotu produktami rolnymi i rybołówstwa. Program Operacyjny SAPARD, zatwierdzony przez Komisję Europejską 18 października 2000 r. ${ }^{39}$, zawierał jedynie drugi ze środków pomocowych ${ }^{40}$. Natomiast już na początku 2002 r. ${ }^{41}$ Zespół-Komitet do spraw Monitorowania SAPARD wprowadził do programu zapis, wskazujący wprost, iż „beneficjentami [Działania 1: Poprawa przetwórstwa i marketingu artykułów rolnych i rybnych - M.B.] mogą być również grupy producentów rolnych oraz ich związki w rozumieniu przepisów ustawy o grupach producentów rolnych i ich związkach"42.

Wraz z przystąpieniem Polski do Unii Europejskiej weszła w życie zmiana $^{43}$ do ustawy o grupach, która uchyliła przepisy dotyczące krajowej pomocy finansowej, zastąpionej pomocą unijną ${ }^{44}$. $Z$ tą datą w nowych krajach członkowskich zaczęły także obowiązywać instrumenty przewidziane w rozporządzeniu nr 1257/99, mające na celu m.in. poprawę przetwarzania i wprowadzenia do obrotu produktów rolnych oraz ułatwienie tworzenia i administracyjnego funkcjonowania grup producentów ${ }^{45}$. Wsparcie dla zakładów przetwórczych przewidziane w krajowym Sektorowym Programie Operacyjnym „Restrukturyzacja i modernizacja sektora żywnościowego i rozwój obszarów wiejskich 2004-2006"46 nie wskazywało bezpośrednio grup producentów jako potencjalnych beneficjentów pomocy. Jednak mając

${ }^{38}$ Rozporządzenie Rady (WE) nr 1268/1999 z 21 czerwca 1999 r. w sprawie wspólnotowych środków pomocowych na rzecz działań przedakcesyjnych w dziedzinie rolnictwa oraz rozwoju obszarów wiejskich w państwach Europy Środkowej i Wschodniej ubiegających się o członkostwo w Unii Europejskiej w okresie przedakcesyjnym (Dz. Urz. UE L 161 z 26.06.1999 r.).

${ }^{39}$ Program Operacyjny dla Polski SAPARD, Ministerstwo Rolnictwa i Rozwoju Wsi, s. 2, http://europa.edu.pl/portal/index/articles/europa?methid=661660091\&page=attachement\& aid=318\&latch $=0$ [dostęp: 18.05 .2021$]$.

${ }^{40}$ Ibidem, s. 71.

${ }^{41}$ Ibidem, s. 3.

42 Ibidem, s. 73, 76.

${ }^{43}$ Zmiany wprowadzono ustawą z 28 listopada 2003 r. o wspieraniu rozwoju obszarów wiejskich ze środków pochodzących z Sekcji Gwarancji Europejskiego Funduszu Orientacji i Gwarancji Rolnej (Dz. U. Nr 229, poz. 2273 ze zm.).

${ }^{44}$ Obwieszczenie Ministra Rolnictwa i Rozwoju Wsi z 15 listopada 2004 r. w sprawie planu rozwoju obszarów wiejskich (M.P. nr 56, poz. 957-959).

${ }^{45}$ Pomoc dla grup przewidziana w art. 33d Traktatu akcesyjnego dotyczyła wyłącznie nowych krajów członkowskich (Dz. Urz. UE L 236 z 23.09.2003 r.).

${ }^{46}$ Załącznik do rozporządzenia Ministra Rolnictwa i Rozwoju Wsi z 3 września 2004 r. (Dz. U. Nr 197, poz. 2032 ze zm.). 
na uwadze, że działanie stanowiło kontynuację instrumentu wsparcia z programu SAPARD, a wnioskodawcą mógł być „przedsiębiorca prowadzący działalność gospodarczą" i planowana inwestycja miała wiązać się z korzyściami dla producentów rolnych ${ }^{47}$, nie budziło wątpliwości to, że grupa producentów może ubiegać się o pomoc jako przetwórca. Ponadto pomoc finansowa dotycząca tworzenia i funkcjonowania grup w ramach równocześnie obowiązującego planu rozwoju obszarów wiejskich ${ }^{48}$ kierowana była także do podmiotów zrzeszających rolników, które wprowadzały na rynek również produkty przetworzone ${ }^{49}$.

\section{Okres 2007-2014}

Rozporządzenie Rady (WE) nr 1698/200550, kluczowe dla kolejnego okresu budżetowego 2007-2013, które zastąpiło m.in. rozporządzenie Rady (WE) nr 1257/1999, kontynuowało, wyłącznie w nowych krajach członkowskich, system pomocy finansowej dla grup producentów (art. 35) oraz wsparcie na inwestycje w zakresie przetwarzania i marketingu produktów rolnych (art. 28). Dla tego drugiego instrumentu Program Rozwoju Obszarów Wiejskich na lata 2007-2013 $3^{51}$ zakładał „wzmocnienie pozycji grup producentów rolnych w kanale marketingowym zbytu produktów, a także szerszy ich udział w uzyskiwaniu wartości dodanej produkcji rolnej poprzez wsparcie inwestycji w zakresie przetwarzania produktów rolnych" ${ }^{2}$. W 2008 r. minister, nowelizując $c^{53}$ przepisy rozporządzenia ustanawiającego

\section{Ibidem.}

48 Obwieszczenie Ministra Rolnictwa i Rozwoju Wsi z 15 listopada 2004 r. w sprawie planu rozwoju obszarów wiejskich (Dz. U. Nr 56, poz. 958 ze zm.).

${ }^{49} \mathrm{~W}$ załączniku pt. „Wykaz produktów lub grup produktów objętych pomocą finansową na wspieranie grup producentów rolnych" do rozporządzenia Rady Ministrów z 19 października 2004 r. w sprawie szczegółowych warunków i trybu udzielania pomocy finansowej na wspieranie grup producentów rolnych objętej planem rozwoju obszarów wiejskich (Dz. U. Nr 238 poz. 2391) wymieniono m.in.: mięsa, podroby, skóry, produkty regionalne.

${ }^{50}$ Rozporządzenie Rady (WE) nr 1698/2005 z 20 września 2005 r. w sprawie wsparcia rozwoju obszarów wiejskich przez Europejski Fundusz Rolny na rzecz Rozwoju Obszarów Wiejskich (EFRROW) (Dz. Urz. UE L 277 z 21.10.2005 r.).

${ }^{51}$ Załącznik do obwieszczenia Ministra Rolnictwa i Rozwoju Wsi z 12 października 2007 r. w sprawie Programu Rozwoju Obszarów Wiejskich na lata 2007-2013 (M.P. nr 94, poz. 1035).

52 Ibidem, s. 208.

${ }_{53}$ Rozporządzenie Ministra Rolnictwa i Rozwoju Wsi z 2 kwietnia 2008 r. zmieniające rozporządzenie $\mathrm{w}$ sprawie szczegółowych warunków i trybu przyznawania pomocy finansowej w ramach działania „Zwiększanie wartości dodanej podstawowej produkcji rolnej i leśnej” objętego Programem Rozwoju Obszarów Wiejskich na lata 2007-2013 (Dz. U. Nr 57, poz. 346). 
warunki wsparcia dla inwestycji w przetwórstwo, stworzył dodatkową, specjalną zachętę dla grup producentów rolnych do pozyskiwania środków na rozpoczęcie lub rozwój takiej działalności przez grupy w postaci wyższego w stosunku do pozostałych wnioskodawców poziomu refundacji poniesionych kosztów kwalifikowalnych operacji ( $\$ 4$ ust. 4 pkt 2 rozporządzenia). Dalsza zmiana ${ }^{54}$ aktu prawnego przyniosła kolejne rozwiązanie mające dać impuls grupom do podejmowania działalności przetwórczej - pierwszeństwo przysługiwania pomocy ( 11 ust. 1 pkt 1 rozporządzenia).

\section{Okres 2014-2020}

Następny okres budżetowy - na lata 2014-2020 - wymagał zmian w legislacji wspólnotowej dotyczącej wspierania rozwoju obszarów wiejskich. Rozporządzenie Parlamentu Europejskiego i Rady (UE) nr 1305/2013 z 17 grudnia 2013 r. w sprawie wsparcia rozwoju obszarów wiejskich przez Europejski Fundusz Rolny na rzecz Rozwoju Obszarów Wiejskich (EFRROW) i uchylające rozporządzenie Rady (WE) nr 1698/2005 ${ }^{55}$ utrzymywało instrumenty pomocy zarówno dla grup producentów, jak i dotyczące przetwarzania i marketingu produktów rolnych.

Dostosowanie przepisów ustawy o grupach do zasad i warunków udzielania pomocy finansowej grupom producentów rolnych określonej w rozporządzeniu nr 1305/2013 legło u podstaw ${ }^{56}$ kolejnej nowelizacji polskiej ustawy ${ }^{57}$. Wśród pozostałych przyczyn zmian projektodawca wskazywał potrzebę dostosowania produkcji osób zrzeszonych w grupie do wyzwań rynku i polityki wspierania konsolidacji pionowej i poziomej producentów rolnych $^{58}$. Ponadto nowela ustawy przyznawała Agencji Restrukturyzacji i Modernizacji Rolnictwa kompetencję do kontrolowania spełniania przez grupy producentów rolnych oraz ich związki warunków uznania tych podmiotów, w przypadku gdy „chcą (one) ubiegać się o przyznanie pomocy w ramach Programu Rozwoju Obszarów Wiejskich na lata 2014-2020 w ramach

${ }^{54}$ Dz. U. z 2013 r., poz. 349 ze zm.

${ }^{55}$ Dz. Urz. UE L 347 z 20.12.2013 r. (dalej: rozporządzenie nr 1305/2013).

${ }^{56}$ Uzasadnienie do rządowego projektu ustawy o zmianie ustawy o grupach producentów rolnych i ich związkach oraz o zmianie innych ustaw oraz ustawy o wspieraniu rozwoju obszarów wiejskich z udziałem środków Europejskiego Funduszu Rolnego na rzecz Rozwoju Obszarów Wiejskich w ramach Programu Rozwoju Obszarów Wiejskich na lata 2014-2020, druk sejmowy nr 3836 (dalej: uzasadnienie do ustawy z 2015 r.), http://www.sejm.gov.pl/Sejm7.nsf/druk. xsp?nr=3836 [dostęp: 11.05.2019].

${ }^{57}$ Dz. U. z 2015 r., poz. 1888 ze zm. (dalej: ustawa z 11 września 2015 r.).

58 Uzasadnienie do ustawy z 2015 r., s. 2. 
poddziałania »Wsparcie inwestycji w przetwarzanie produktów rolnych, obrót nimi lub ich rozwój «" 59 , które stanowi kontynuację instrumentu ustanowionego w PROW 2007-2013 ${ }^{60}$. Zasadę pierwszeństwa grup producentów rolnych przed innymi wnioskodawcami $\mathrm{w}$ dostępie do pomocy uwzględnia też obecnie obowiązujące rozporządzenie ${ }^{61}$ regulujące zasady wsparcia inwestycji w przetwarzanie lub obrót produktami rolnymi.

\section{Nowelizacja ustawy o grupach z 2015 r.}

Nowelizacja ustawy o grupach z 2015 r., oprócz zmian związanych $\mathrm{z}$ dostosowaniem do przepisów rozporządzenia $\mathrm{nr}$ 1305/2013 ${ }^{62}$, wprowadziła także zmiany m.in. w zakresie celów działania organizacji, warunków uznania czy kontroli nad nimi ${ }^{63}$. Po wejściu w życie przepisów znowelizowanej ustawy w praktyce pojawiły się wątpliwości dotyczące dopuszczalności przetwarzania przez grupę produktów pochodzących z gospodarstw jej członków.

W trakcie postępowania prowadzonego przez dyrektora Oddziału Terenowego Agencji Rynku Rolnego, a dotyczącego potwierdzenia spełniania warunków określonych $\mathrm{w}$ art. 3 ustawy o grupach ${ }^{64}$ przez jedną z grup producentów mleka, organ ów wyraził stanowisko, potwierdzone następnie przez prezesa ARR, jakoby ,intencją ustawodawcy było ograniczenie sprzedaży [grupy - M.B.] wyłącznie do produktu [mleka-M.B.] nieprzetworzonego" ${ }^{\prime 2}$. W sprawie głos zabrał minister rolnictwa i rozwoju wsi ${ }^{66}$, który poparł dopuszczalność prowadzenia działalności przetwórczej, zwracając jednocześnie uwagę na uzasadnienie do rządowego projektu, z którego wynikało, iż ,zmiany w zaproponowanym brzmieniu [uchylenie pkt $3 \mathrm{w}$ art. 4 ust. 1 - M.B.] wprowadzą możliwość przetwarzania przez grupy producentów

${ }^{59}$ Ibidem, s. 11.

${ }^{60}$ Dz. U. z 2008 r., Nr 57, poz. 346 ze zm.

${ }^{61}$ Rozporządzenie Ministra Rolnictwa i Rozwoju Wsi z 5 października 2015 r. w sprawie szczegółowych warunków i trybu przyznawania oraz wypłaty pomocy finansowej w ramach poddziałania „Wsparcie inwestycji w przetwarzanie produktów rolnych, obrót nimi lub ich rozwój” objętego Programem Rozwoju Obszarów Wiejskich na lata 2014-2020 (Dz. U. poz. 1581 ze zm.).

${ }^{62}$ Uzasadnienie do ustawy z 2015 r., s. 2.

${ }^{63}$ A. Suchoń, $Z$ aktualnej problematyki...

${ }^{64}$ Na podstawie art. 4 ust. 1 pkt 1 ustawy z 11 września 2015 r. o zmianie ustawy o grupach producentów rolnych i ich związkach oraz o zmianie innych ustaw oraz ustawy o wspieraniu rozwoju obszarów wiejskich z udziałem środków Europejskiego Funduszu Rolnego na rzecz Rozwoju Obszarów Wiejskich w ramach Programu Rozwoju Obszarów Wiejskich na lata 2014-2020 (Dz. U. poz. 1888).

${ }_{65}$ Pismo Prezesa ARR z 19 stycznia 2017 r. (udostępnione autorowi przez adresata).

${ }^{66}$ Pismo Ministra Rolnictwa i Rozwoju Wsi z 10 marca 2017 r. (udostępnione autorowi przez adresata), s. 4. 
rolnych produktów lub grup produktów, ze względu na które grupa została utworzona, a które zostały wytworzone w gospodarstwach członków grupy w odniesieniu do całej wielkości produkcji członków grupy" ${ }^{67}$. Projektodawca ${ }^{68} \mathrm{z}$ jednej strony potwierdził, że $\mathrm{w}$ stanie prawnym ukształtowanym w wyniku wejścia w życie ustawy z 11 września 2015 r. grupa producentów rolnych może przetwarzać produkty dostarczone przez swoich członków; $\mathrm{z}$ drugiej - uznał, że przed wejściem w życie nowelizacji wprowadzanie do obrotu przez grupy producenckie produktów pochodzących z gospodarstw członków i przez grupy przetworzonych, choć było możliwe, to miało być zarazem ograniczone ilościowo wyłącznie do tej części produkcji członków, która przewyższała limity ustanowione na podstawie art. 6 ustawy o grupach $^{69}$. W praktyce miało to oznaczać, iż grupa producentów np. mleka krowiego, mogłaby poddać przetworzeniu jedynie tę część dostaw surowca pochodzącego z gospodarstw swoich członków, która przewyższałaby wyznaczony przepisem limit 100 tys. litrów ${ }^{70}$.

W opinii inicjatorów procesu legislacyjnego z 2015 r., potwierdzonej stanowiskiem ministra rolnictwa i rozwoju wsi ${ }^{71}$, zmiana podejścia wyrażała się zastąpieniem „,sprzedaży za pośrednictwem grupy” (art. 4 ust. 1 pkt 4 w dotychczasowym brzmieniu) przez, ,sprzedaż do grupy” (art. 3 ust. 1 pkt 6 po zmianie). Jednak zredukowanie obowiązku członków do sprzedaży „do” grupy z równoczesnym usunięciem związanego z tą sprzedażą obowiązku dalszej sprzedaży tego produktu przez grupę jako pośrednika (,za pośrednictwem”) nie oznacza, że przed nowelizacją dopuszczalność przetwarzania produktów pochodzących z gospodarstw członków doznawała ograniczenia ilościowego. Trzeba zauważyć, że wyrażenie „sprzedaż za pośrednictwem grupy" nie oznacza per se, że produkt dostarczony przez członka do grupy nie mógłby zostać przez grupę przetworzony i w takiej postaci wprowadzony na rynek. Szczególnie wtedy, gdy po takim procesie nadal byłby produktem rolnym, a takim pojęciem posługuje się od 2000 r. ustawodawca w art. 3 ust. 1 pkt 1 (i art. 3 a pkt 1) ustawy o grupach. $\mathrm{Z}$ art. 38 ust. 1 Traktatu o funkcjonowaniu Unii Europejskiej wynika natomiast wprost, że przez „produkty rolne” należy rozumieć „również produkty pierwszego

${ }^{67}$ Uzasadnienie do ustawy z $2015 \mathrm{r}$.

${ }^{68}$ Projekt zmiany ustawy był projektem rządowym, przygotowanym w Ministerstwie Rolnictwa i Rozwoju Wsi.

${ }^{69}$ Wynikający z rozporządzenia Ministra Rolnictwa i Rozwoju Wsi z 9 kwietnia 2008 r. w sprawie wykazu produktów i grup produktów, dla których mogą być tworzone grupy producentów rolnych, minimalnej rocznej wielkości produkcji towarowej oraz minimalnej liczby członków grupy producentów rolnych (Dz. U. Nr 72, poz. 424 ze zm.).

${ }_{70}$ Ibidem.

71 Pismo Ministra Rolnictwa i Rozwoju Wsi z 10 marca 2017 r. 
przetworzenia, które pozostają w bezpośrednim związku z tymi produktami”, co potwierdza załącznik nr I do Traktatu, który wśród produktów rolnych wymienia expressis verbis produkty w formie przetworzonej (np. ,produkty mleczarskie”, „mięso") ${ }^{72}$.

Ponadto uchylany przepis art. 4 ust. 1 pkt 4 ustawy o grupach ustalał jedno z obligatoryjnych wymagań aktu założycielskiego grupy i wyrażał bezwzględny warunek zawarcia w nim obowiązku sprzedaży przez członków grupy całości produktów lub grupy produktów za jej pośrednictwem. Trzeba podkreślić, że jednocześnie dopuszczał odstępstwa od tej zasady, nie wyznaczając przy tym organizacjom granicy w ich kształtowaniu.

Wydaje się, że autorzy stanowiska wyrażonego w uzasadnieniu do ustawy nie dostrzegli liczącej sobie wówczas kilkanaście lat historii legislacji z zakresu wsparcia inwestycji w przetwarzanie i marketing produktów rolnych przez grupy producentów, zarówno w okresie przedakcesyjnym, jak i po wstąpieniu Polskie do UE. I także z tego powodu, poza wskazanymi powyżej, pogląd ten jest nietrafny. Nie da się go bowiem pogodzić z jednym z celów prawodawstwa wspólnotowego i krajowego, jakim jest wzmacnianie pozycji producentów rolnych w łańcuchu żywnościowym oraz sprzyjanie zwiększaniu ich udziału w wartości dodanej. W tym świetle wyłączanie części produktów rolnych dostarczonych do grup z procesu przetwarzania, który ma prowadzić do wzrostu marży, nie znajduje uzasadnienia.

Pewne wątpliwości rodzi też treść rozporządzenia ${ }^{73}$ Ministra Rolnictwa i Rozwoju Wsi wydanego na podstawie upoważnienia zawartego w art. 6 ustawy o grupach. W pozycjach wykazu produktów i grup produktów, które obejmują zarówno surowe produkty rolne, jak i przetworzone (np. „bydło żywe: zwierzęta rzeźne i hodowlane, mięso wołowe: świeże, chłodzone, mrożone"), minimalna roczna wielkość produkcji towarowej została wyrażona w jednostce właściwej dla produktu surowego - ,sztuka”. Mogłoby to sugerować, że wyłącznie w takiej formie producent rolny może sprzedać swój produkt do grupy (,za pośrednictwem grupy” w brzmieniu sprzed 18 grudnia 2015 r.). Skoro jednak prawodawca dopuszcza do tworzenia grup w kategorii „mięso wołowe”, to należy uznać, że minimalna roczna wielkość produkcji towarowej dla tego konkretnego przykładu, wyrażona w sztukach, będzie oznaczać ilość mięsa wołowego pochodzącego z określonej liczby sztuk wyprodukowanych w gospodarstwach członków.

${ }^{72}$ A. Jurcewicz, B. Kozłowska, E. Tomkiewicz, Polityka Rolna..., s. 21-24.

${ }^{73}$ Rozporządzenie Ministra Rolnictwa i Rozwoju Wsi z 4 lipca 2003 r. w sprawie wykazu produktów i grup produktów, dla których mogą być tworzone grupy producentów rolnych, minimalnej rocznej wielkości produkcji towarowej oraz minimalnej liczby członków grupy producentów rolnych (Dz. U. Nr 138, poz. 131 ze zm.). 
Nieco inaczej sprawa będzie się miała z pozycjami wykazu, które obejmują wyłącznie surowe produkty rolne, np. „mleko krowie”. W tym przypadku wydaje się, że osoba prowadząca gospodarstwo rolne zobowiązana jest sprzedać do grupy mleko krowie wyłącznie w postaci nieprzetworzonej, w minimalnej ilości wyrażonej w litrach, skoro ustawowo upoważniony organ - minister nie uwzględnił w tym wykazie, oprócz produktu surowego (mleko), jego przetworów. Natomiast w sytuacji, gdy grupa przetwarza mleko, istotnym problemem może stać się kwestia obliczenia maksymalnej, dopuszczalnej ilości mleka zakupionego od producentów spoza grona członków grupy (art. 3 ust. 1 pkt 4 ustawy o grupach). Należy wówczas przeprowadzić stosowne obliczenia w celu ustalenia udziału ilości mleka pochodzącego od członków grupy i producentów spoza tego grona w produktach mleczarskich wytworzonych i sprzedanych przez grupę.

\section{Wnioski}

Powyższe rozważania pozwalają na sformułowanie kilku wniosków stanowiących odpowiedź na postawione we wstępie pytanie: czy w świetle przepisów prawa krajowego i wspólnotowego uznane grupy producentów mogą przetwarzać produkty rolne dostarczone przez członków lub podmioty spoza tego grona, by potem wprowadzać je do obrotu.

Po pierwsze, analizy przepisów polskiej ustawy regulującej powstawanie i uznawanie grup producentów rolnych, wzorowanych na przepisach wspólnotowych, nie sposób dokonać bez przeglądu systemu prawa unijnego, w którym począwszy od pierwszych regulacji, nie ulegało wątpliwości, że grupy producentów mogą przetwarzać produkty rolne. Przy jego tworzeniu pojawiały się nawet postulaty, by przyznać im preferencje $\mathrm{w}$ dostępie do pomocy finansowej na projekty inwestycyjne w zakresie przetwórstw i marketingu. Idea ta obejmowała również specjalne kursy instruktażowe oraz szkolenia dla liderów i menedżerów grup producentów, wspierające poprawę organizacji gospodarczej oraz przetwarzanie i wprowadzanie do obrotu produktów rolnych ${ }^{74}$.

Po drugie, już pierwsze akty legislacji wspólnotowej sprzed ponad 40 lat potwierdzają leżące u ich podstaw przekonanie, że kwestii marketingu i przetwórstwa nie należy oddzielać od produkcji, gdzie celem powinno być m.in. zwiększenie dochodów społeczności rolniczej i ochrona jej interesu

${ }^{74}$ Art. 21 rozporządzenia Rady (EWG) nr 797/85 z 12 marca 1985 r. w sprawie zwiększania wydajności struktur rolnych (Dz. Urz. UE L 93 z 30.03.1985 r.). 
w obliczu rosnącej koncentracji nabywców, a grupy producentów rolnych, w szczególności spółdzielnie, mające doświadczenie w przetwórstwie, powinny w tym procesie odegrać kluczową rolę.

Po trzecie, programy pomocy finansowej ze środków unijnych - od przedakcesyjnego SAPARD przez SPO 2004-2006, po PROW 20072013 i 2014-2020 - nie tylko przewidywały możliwość udzielania, ale wręcz zachęcały do korzystania z dotacji na poprawę przetwórstwa i obrotu produktami rolnymi i rybołówstwa przez grupy producentów.

Po czwarte, wsparcie rozwoju grup producentów oraz inwestycji w przetwórstwo i marketing stanowi integralną część strategii poprawy struktur rolnych, które zgodnie z założeniami Traktatu powinny wspierać dochody rolników. Próbę pozbawienia grup producentów prawa do przetwarzania produktów pochodzących z gospodarstw ich członków należałoby więc uznać za sprzeczną z celami ${ }^{75}$ Wspólnej Polityki Rolnej wynikającej z prawa pierwotnego Unii Europejskiej.

W świetle powyższych wniosków uzasadnione jest więc twierdzenie, że przetwarzanie produktów rolnych przez grupy producentów można uznać za prawnie dozwolone, a mając na uwadze cele Wspólnej Polityki Rolnej i system krajowych preferencji w dostępie do pomocy na inwestycje - za pożądane. Będzie to dotyczyć zarówno sytuacji, w której członkowie produkują i dostarczają do grupy surowy produkt rolny, a grupa (własnymi zasobami lub usługowo) przetwarza go, a następnie wprowadza do obrotu, jak i sytuacji, w której członkowie produkują, a następnie przetwarzają produkt rolny, który dostarczają do grupy, a grupa poddaje go dalszemu przetworzeniu, po czym wprowadza do obrotu.

\section{BIBLIOGRAFIA}

Barcik J., Wentkowska A. (2014), Prawo Unii Europejskiej, Warszawa.

Chlebicka A., Fałkowski J., Wołek T. (2009), Powstawanie grup producenckich a zmienność cen, „Zagadnienia Ekonomiki Rolnej” nr 2.

Czapiewska G. (2013), Grupy producentów rolnych w rozwoju obszarów wiejskich Pomorza, „Acta Universitatis Lodziensis. Folia Geographica Socio-Oeconomica” nr 13.

Jurcewicz A., Kozłowska B., Tomkiewicz E. (1995), Polityka Rolna Wspólnoty Europejskiej $w$ świetle ustawodawstwa i orzecznictwa, Warszawa.

Jurcewicz A., Kozłowska B., Tomkiewicz E. (2007), Wspólna Polityka Rolna. Zagadnienia prawne, Warszawa.

${ }^{75}$ O prymacie celowościowej (funkcjonalnej) wykładni przepisów prawa UE: J. Barcik, A. Wentkowska, Prawo Unii Europejskiej, Warszawa 2014, s. 313-315; A. Jurcewicz, B. Kozłowska, E. Tomkiewicz: Wspólna Polityka ..., s. 58; S. Wronkowska, Podstawowe pojęcia i prawa i prawoznawstwa, Poznań 2005, s. 103. 
Lemanowicz M. (2004), Grupy producenckie i marketingowe i ich wpływ na pozycję konkurencyjna rolników na rynku, „Acta Scientiarum Polonorum. Oeconomia” nr 3.

Lichorowicz A. (1996), Problematyka struktur agrarnych w ustawodawstwie Wspólnoty Europejskiej, Kraków.

Łęczycki K. (red.) (2007), Ogólne problemy rozwoju grup producenckich w rolnictwie, Siedlce. Oleszko-Kurzyna Bożena (2007), Postawy rolników wobec grup producentów rolnych, „Annales Universitatis Mariae Curie-Skłodowska, Sectio H Oeconomia” nr 41.

Parzonko A. (red.) (2008), Sposoby wspótpracy doradców z rolnikami zorganizowanymi $w$ grupy producentów rolnych, Warszawa.

Suchoń A. (2015), Grupy i organizacje producentów rolnych wobec wyzwań Wspólnej Polityki Rolnej 2014-2020, „Studia Iuridica Agraria” nr 13.

Suchoń A. (2016), Z aktualnej problematyki zakładania i funkcjonowania grup producentów rolnych, „Przegląd Prawa Rolnego” nr 2.

Wronkowska S. (2005), Podstawowe pojęcia i prawa i prawoznawstwa, Poznań.

\section{MARKET ADMISSIBILITY OF PRODUCTS PROCESSED BY AGRICULTURAL PRODUCER GROUPS}

\section{Sum mary}

The aim of the article was an attempt to answer the question whether, in the light of the current provisions of EU law and Polish law, it is possible for recognised groups of agricultural producers to market products supplied by their members as well as entities from outside the group. This issue has not been addressed in the literature but it is of a significant practical value. The processing of agricultural products by groups recognised as such pursuant to the Act on agricultural producer groups and their associations has a direct impact on the assessment whether these groups have satisfied the conditions for recognition, which means whether they will retain or lose this status and, therefore the privileges related to it in the form of financial aid from the EU funds, tax exemptions or subsidies to preferential credits. The primary and secondary European Union law and regulations concerning financial aid from EU funds, as well as the relevant judgment of the Court of Justice in the matter in question have been analysed with a conclusion leading to an affirmative answer to the question posed.

Keywords: groups of agricultural producers, structural policy, common agricultural policy

\section{SUL PROBLEMA DI IMMETTERE IN COMMERCIO I PRODOTTI TRASFORMATI DA GRUPPI DI PRODUTTORI AGRICOLI}

$$
\text { Riassunto }
$$

L'articolo si propone di rispondere alla domanda se permettere, alla luce della vigente normativa dell'Ue e di quella nazionale, ai gruppi riconosciuti di produttori agricoli di immettere in commercio i prodotti trasformati, forniti loro da soci o soggetti al di fuori del gruppo. Finora il problema non è stato discusso in letteratura, nonostante una significativa dimensione 
pratica. La questione di come i prodotti vengano trasformati ha un impatto diretto sul processo in cui si valuta se i gruppi di produttori agricoli (che conseguono il riconoscimento ai sensi della legge sui gruppi di produttori agricoli e le loro associazioni) continueranno a soddisfare i criteri per il riconoscimento accordato, e di conseguenza se riusciranno a mantenere lo status assegnato, e in realtà i relativi privilegi, quali aiuti finanziari provenienti da fondi dell'Ue, esenzioni fiscali, agevolazioni sui prestiti preferenziali. L'autore analizza il diritto comunitario primario e secondario, nonché le disposizioni concernenti il contributo finanziario proveniente da fondi dell'Unione europea, come anche la sentenza della Corte di giustizia. Le conclusioni portano a dare una risposta affermativa alla domanda posta.

Parole chiave: gruppi di produttori agricoli, politica strutturale, politica agricola comune 